\title{
AS MULHERES DO INÍCIO DO SÉCULO XX E O TRABALHO FORA DO LAR: indícios através do design dos reclames dos Almanachs de Pelotas
}

\author{
Paula Garcia Lima \\ Universidade Federal de Pelotas \\ paulaglima@gmail.com \\ Francisca Ferreira Michelon \\ Universidade Federal de Pelotas \\ fmichelon.ufpel@gmail.com \\ Caroline Farias Ferreira \\ Universidade Federal de Pelotas \\ carolinefariasferreira@gmail.com \\ Saarah Londero Maschendorf Gottinari \\ Universidade Federal de Pelotas \\ saarahgottinari@gmail.com
}

\begin{abstract}
Resumo: Este texto foi motivado pelo encontro de dois reclames veiculados nos Almanachs de Pelotas, periódico editado nesta cidade, localizada ao sul do Rio Grande do Sul. A referida publicação foi editada entre os anos de 1913 e 1935, mas os anúncios analisados referem-se aos anos de 1925, 1926, 1927, 1930 e 1931 e foram motivadores da presente reflexão por permitirem trazer à tona as relações das mulheres com o trabalho fora do lar no início do século XX. Esses reclames são abordados como peças nas quais o design gráfico está presente, embasando esta postura através de quatro correntes que localizam temporalmente o início da história do design (VILLAS-BOAS; BRAGA, 2013) e através do conceito desta atividade (VILLAS-BOAS, 2000 e HOLLIS, 2000). Os outros assuntos que embasam a discussão são: os almanaques e o contexto (DENIS, $2000 \mathrm{e}$ DUTRA, 2005), o cenário da cidade (CUNHA, 2009) e as mulheres e sua inserção no trabalho (PERROT, 2012). Ao final, conclui-se que o design está intimamente atrelado ao contexto e a cultura nos quais circulou e, no caso do que foi analisado, fornecendo dados acerca das relações entre os gêneros e da inserção das mulheres no trabalho.
\end{abstract}

Palavras-chave: Design Gráfico, Almanachs de Pelotas, reclames, trabalho, mulheres do século XX. 


\begin{abstract}
This text was motivated by the meeting of two ads found in the Almanachs de Pelotas, periodical published in this city, located in south of the Rio Grande do Sul. That publication was edited between the years 1913 and 1935, but the ads analyzed refer to years 1925, 1926, 1927, 1930 and 1931 and were motivators of this reflection by allowing to tease out the relationships of women work outside the home in the early twentieth century. These ads are addressed as pieces where graphic design is present, basing this position through four chains that locate temporally the start of design history (VILLAS - BOAS , BRAGA , 2013), and through the concept of this activity (VILLAS - BOAS, 2000 and Hollis, 2000). The other issues that underlie the discussion are: almanacs and context (DENIS, 2000 and Dutra, 2005), the city scenery (Cunha, 2009) and women and their insertion into work (Perrot 2012). Finally, it is concluded that the design is closely linked to the context and culture in which circled, and in the case of what was analyzed, providing information about the relationship between gender and the insertion of women at work.
\end{abstract}

Keywords: Graphic Design, Almanachs de Pelotas, ads, work, women of the twentieth century.

\title{
1. INTRODUÇÃO
}

O presente artigo é oriundo de reflexões desencadeadas na elaboração da tese que está sendo desenvolvida dentro do Programa de Pós-Graduação em Memória Social e Patrimônio Cultural da Universidade Federal de Pelotas e de investigações dentro no grupo de pesquisa "Memória Gráfica de Pelotas: um século de design", lotado na mesma universidade. O referido programa de pós-graduação por si já é um indicativo do caráter interdisciplinar da pesquisa e das aproximações que são feitas da área do design com a cultura e a história.

A proposta de tese tem por finalidade analisar as memórias das mulheres através dos reclames presentes nos Almanachs de Pelotas, editados na cidade de Pelotas, cidade ao sul do Rio Grande do Sul, entre os anos de 1913 e 1935. Importante mencionar que, mesmo em se tratando de um período anterior a existência da palavra design, o trabalho visa compreender estes reclames como produtos nos quais o design gráfico se faz presente, por conclusões traçadas em Lima (2010). Para pautar esta discussão se tomou como base os estudos de Villas-Boas (2000) e Villas-Boas e Braga (2013). Com relação ao tema almanaques e contexto são trazidas algumas informações de Denis (2000) e Dutra (2005). Sobre a cidade o trabalho fundamentou-se em autores locais, como Cunha (2009). Já para o tema mulheres a autora referência é Perrot (2012).

O Almanach de Pelotas foi um periódico anual que, assim como as demais publicações do gênero, era composto por assuntos de temas variados. Este objeto de estudo contemplava desde assuntos relacionados às questões de utilidade pública (taxas de correios e telégrafos, datas para pagamentos de impostos, horários do bonde, serviços) até aqueles que tinham o cunho apenas de entreter e divertir o leitor. No decorrer de suas 23 edições, foi contabilizado um total de 4221 anúncios, que resulta numa média de 183 anúncios por edição - número que se considera bastante avultado. Esta quantia significativa justifica-se pelo financiamento do periódico, que 
em inúmeros de seus editoriais exaltava que mesmo com o valor crescente dos insumos necessários para a sua produção a luta era para manter o Almanach em circulação, sem visar lucro. Os editores explanavam que objetivavam que a publicação fosse um produto promulgador do progresso da cidade e do trabalho e grandes feitos de seus cidadãos. Com tais fatos, os anúncios devem ter desempenhado um papel fundamental para a sobrevivência do periódico.

Neste considerável número de anúncios pode-se encontrar uma série de dados que permitem pensar a sociedade daquele período e daquele local. Inúmeras são as vertentes que estes permitem desvendar. No entanto, o que aqui se apresenta, é uma reflexão sobre as relações entre as mulheres do início do século XX e o trabalho além do espaço da casa, a partir de dois anúncios: Elisa Camorali - professora de datilografia, presente nas edições de 1925, 1926 e 1927 e anúncio da Cafiaspirina medicamento, encontrado nas páginas das edições de 1930 e 1931.

\section{DESENVOLVIMENTO}

\subsection{Os Almanachs, seus reclames e o design}

Os Almanachs de Pelotas configuram objetos de estudo cuja análise traz inúmeras informações sobre a sociedade da época: hábitos, costumes, aspectos sobre a vida financeira, atividades, serviços e etc.. Tais dados têm uma veracidade maior ao se pensar que esta tipologia de publicação era extremamente popular e bem quista pelo público, dado o grande número de periódicos deste gênero no período estudado.

A proliferação deste tipo de publicação, neste período, deveu-se a uma tradição que foi sendo construída ao longo de muitos anos. Os primeiros almanaques remontam ao século XV, em função da impressão em larga escala, graças à invenção dos tipos móveis por Gutenberg. Entre os séculos XVIII e XIX os almanaques se tornaram veículos de instrução e de propaganda, assumindo, em alguns casos, vieses temáticos. A partir da Revolução Industrial e durante o século seguinte, quando grande parte da população migrou para as cidades, os almanaques disseminaram-se concomitantemente ao aumento de novos leitores, que viam na atividade de leitura uma opção de lazer (DUTRA, 2005, p.16-18). Este fato é destacado, também, por Denis (2000, p.78-81), ponderando que a partir de meados do século XIX houve a democratização do consumo de produtos considerados de luxo ou supérfluos através do crescimento no número de pessoas capazes de adquirir artigos além daqueles de primeira necessidade. Dentre estes tipos de produto se enquadram as atividades de entretenimento, como a leitura, por exemplo.

Os Almanachs de Pelotas foram todos confeccionados a partir da técnica tipográfica com a presença de clichês fotográficos. Nas publicações de 1913 a 1920 as impressões foram realizadas pelas Officinas Typográficas do Diário Popular (oficina de jornal da cidade em circulação até os dias de hoje); de 1921 a 1928 as edições foram impressas na Tipografia Guarany; e de 1929 a 1935 as impressões se deram nas Oficinas tipográficas da Livraria do Globo (GASTAUD e SILVA, 2010, p. 12). Era impresso em papel jornal e tinha dimensões de $29 \times 21 \mathrm{~cm}$, no formato aberto.

No entanto, este periódico configura o contexto maior do objeto mais específico que se está a pesquisar: os seus reclames. Estes anúncios, assim como as 
publicações em questão, também são fontes que podem fornecer inúmeros dados sobre o cenário no qual circularam. A demanda por este ou aquele produto/serviço e a linguagem adotada para estabelecer comunicação com o público podem fornecer muitas informações. Que público era este? Que mulher era esta? É neste rumo que se busca traçar a reflexão deste texto.

As propagandas (reclames ou anúncios, como se está a nominar aqui), segundo Funck (2007, p.190), esclarecem as relações entre os atores (homens, mulheres), de um dado contexto, pois "propagandas em geral são um excelente campo para se entender a construção discursiva de gênero (...)". A autora relata que é comum ver publicitários tecerem discursos pautados na ideia de que a propaganda é uma representação do mundo, no entanto, esta representação é uma forma de construção. Deste modo, os reclames, ao mesmo tempo que podem ser espelhos do contexto, têm um papel nada ingênuo na instauração de ideologias, papeis, funções e comportamentos das pessoas que constituem uma sociedade. É por este raciocínio que se quer compreender um pouco das relações das mulheres com o mundo do trabalho através de dois anúncios que serão apresentados mais adiante.

Estes reclames, conforme mencionado na introdução, são considerados a partir da ótica do design gráfico. De fato, este termo ainda não havia sido cunhado neste período, mas o intuito é perceber que o produto, em si, poderia ser um produto desta atividade profissional, hoje melhor delimitada, porém ainda imprecisa. Alguns estudos pautam-se na definição do que é design gráfico e quando esta atividade surgiu. Autores importantes localizam peças de design em tempos remotos, como Meggs e Purvis (2009, p.18-33), os quais, ao sugerirem a história do design gráfico, recorrem às pinturas pré-históricas nas cavernas, à escrita suméria e às manifestações gráficas dos egípcios.

Inúmeras são as posturas com relação ao início da história do design, tanto que Villas-Boas e Braga (2013) desenvolveram um trabalho com vistas a esboçar as diferentes concepções acerca dessa localização temporal e definições de design gráfico encontradas em autores importantes e presentes nas orientações historiográficas identificadas e utilizadas no Brasil.

Neste texto, os autores destacaram quatro correntes balizadoras para traçar a história do design gráfico. A primeira corrente concebe que esta atividade teria tido início na Pré-História ou na Antiguidade, considerando, apenas, os aspectos comunicativos e organizacionais da comunicação visual, sendo considerado o design um processo intrínseco nos seres humanos. A segunda corrente é partidária da ideia de que esta atividade está associada à invenção dos tipos móveis por Gutenberg no século $X V$, os quais permitiram a produção de impressos em série. (VILLAS-BOAS e BRAGA, 2013, p.26-27)

Neste mesmo rumo, Denis (2000, p.17) defende que um dos marcos fundamentais para a caracterização do design foi, justamente, o momento em que os processos de fabricação passaram pela distinção entre as tarefas de projetar e executar, cabendo ao designer executar o projeto de um objeto que será fabricado por outras pessoas ou através de meios mecânicos. Ainda de acordo com o autor, a inserção de meios mecânicos no processo de fabrico remete, pelo menos, ao século e a autoria referidos no parágrafo acima.

Embora os impressos produzidos neste período já contemplassem os quesitos citados como produção seriada por meio mecânico e com distinção entre projeto e 
execução, tais aspectos foram realmente potencializados no decorrer dos séculos XVII e XVIII (DENIS, 2000, p.17). Ressalta-se, inclusive, que este autor, em outra de suas obras, aponta que o termo design, em sua acepção moderna, aplica-se por excelência na segunda metade do século XVIII (CARDOSO, 2005, p. 160).

A potencialização mencionada acima não se deu por acaso, pois foi neste contexto que emergiram inúmeras agitações que acabaram levando à eclosão da Revolução Industrial - ocorrida, inicialmente, na Inglaterra entre os anos 1760 e 1840 - que trouxe consigo inúmeras mudanças sociais e econômicas. A energia possibilitou a substituição da força humana e animal, gerando um grande aumento na produtividade que, por sua vez, permitiu uma maior divisão do trabalho (MEGGS e PURVIS, 2009, p.174).

É nesta égide que se ampara a terceira linha de pensamento, aquela pautada na concepção de que o design surgiu na segunda fase da Revolução Industrial, quando em meados do século XIX ocorreram melhorias nas tecnologias (automatização, mais recursos para projetos, redução de custos e aumento da produção) que possibilitaram atender as demandas da sociedade de massas. (VILLAS-BOAS e BRAGA, 2013, p.27-28)

Por último, a quarta corrente define como marco inicial o século $\mathrm{XX}$, por considerar que foi neste momento que se passou a identificar a existência de uma metodologia específica, de produção simbólica, de capacidade de produção e reprodução da cultura de massa, delimitando a atividade como uma área específica. (VILLAS-BOAS e BRAGA, 2013, p.28-29)

Embora as autoras deste artigo tenham um repertório maior que localiza o design a partir do postulado pela terceira linha de pensamento aqui exposta, cabe destacar que não se quer aqui defender uma ou outra corrente. Com esta exposição se pretende, apenas, considerar que os reclames analisados podem ser considerados peças de design gráfico. Em qualquer uma destas correntes, mesmo na última, se poderia encontrar apoio neste sentido.

Porém, prefere-se estipular como algo sendo ou não design gráfico, com base naquilo que define a atividade, ou seja, com base no seu conceito. A discussão sobre a temática do conceito é ampla e pode ser bastante complexa, no entanto, não é o objetivo maior deste texto. Logo, brevemente se apresentam os conceitos que se consideram suficientes para prosseguir na reflexão aqui proposta.

Para Hollis (2000, p.4), design é uma área cujos produtos têm por funções identificar; informar e instruir; e apresentar e promover. No entanto, cabe-se complementar este conceito com Villas-Boas (2000, p.8-12), autor que observa que uma peça gráfica será considerada design se contiver, em si, aspectos formais, funcionais, metodológicos e simbólicos. Avalia-se a questão do simbólico como fundamental para a eficiência da transmissão de ideias e conceitos a um determinado público, de forma contextualizada a um dado tempo e espaço. Em Lima (2010), após identificar que os três primeiros aspectos eram mais evidentes em peças gráficas do início do século $\mathrm{XX}$, foi justamente o aspecto simbólico que se intentou verificar a existência nas mesmas, com vistas a considerá-las ou não como peças nas quais o design se fazia presente. A conclusão foi que as peças continham inúmeros significados simbólicos, configurando-as, então, como produtos desta atividade profissional. É com base nestes conceitos e nesta conclusão que se orienta a ideia de que os reclames aqui apreciados, contemplam a definição de design gráfico que se tem hoje, mesmo que a atividade com esta nomenclatura ainda não existisse. 


\subsection{As mulheres e o contexto}

A inserção das mulheres no mercado de trabalho ainda é um tema que gera polêmica. Hoje é comum encontrarmos mulheres em diferentes tipos de profissão, inclusive aquelas consideradas "masculinas" como motoristas de ônibus e delegadas, por exemplo. No entanto, no quesito valorização e equiparação aos cargos e salários dos homens, ainda há muito que avançar. Tudo isso (gerar polêmica e o desaprecio com relação ao gênero masculino) ocorre, justamente, em função de um longo tempo, não tão distante assim, no qual era reservado às mulheres somente o espaço do lar. Sim, as mulheres sempre trabalharam, no entanto, no passado somente entre as paredes de suas casas. $\mathrm{O}$ caminho percorrido até os dias de hoje foi longo e segue em curso.

A autora Michelle Perrot (2012, p.109-124), desenvolve a trajetória das mulheres no trabalho, mencionando as suas atuações como camponesas, donas de casa, empregadas domésticas, operárias (principalmente no ramo têxtil, a partir da Primeira Revolução Industrial, e no ramo da costura) e, posteriormente suas inserções no setor terciário como vendedoras, secretárias, enfermeiras e professoras primárias. Estas profissões no setor terciário remontam aos séculos XIX e XX, sendo que foi neste último século a veiculação dos anúncios que serão apreciados, os quais, justamente, se referem a duas destas profissões: enfermagem e docência.

A figura da mulher enfermeira teve como marco importante a Guerra da Crimeia, nos anos 1850, quando a britânica Florence Nightingale organizou um serviço de enfermagem para cuidar dos soldados atingidos pelos combates. Antes, estes préstimos eram funções das religiosas de asilos e hospitais. Já as professoras tiveram o seu surgimento associado ao momento em que escola se tornou obrigatória para os dois sexos. Cabia as mulheres ensinar meninas e crianças menores, tendo esta profissão se tornado um desejo das mulheres advindas de classes mais humildes e que necessitavam trabalhar. (PERROT, 2012, p.125-126)

Após esta contextualização mais ampla, traz-se a discussão para mais próximo do cenário onde as publicações e os seus reclames circularam: a cidade de Pelotas. Cidade localizada ao sul do Rio Grande do Sul, foi fundada em 1835. Economicamente apoiada na produção das charqueadas (a primeira data de 1780), se desenvolveu e cresceu, tornando-se, no século XIX, uma das cidades mais adiantadas e prósperas do estado (CUNHA, 2009, p.30-31). Foi neste século, também, que a cidade desenvolveu seu cenário urbano e, junto com ele, um ambiente cultural que manteve grande destaque até o século XX (IDEM, p.33). Neste contexto Pelotas vivia a sua Belle Époque, pois de acordo com Marroni (2008, p.27) a cidade vivenciava inúmeras experiências e fatos culturais como explosão da imprensa, na segunda metade do século XIX, além do surgimento da Guarani Films em 1914, a re-inauguração do Theatro Sete de Abril em 1916, a inauguração do Theatro Guarany em 1921 e a proliferação do comércio em diversos segmentos. O desenvolvimento do comércio pode ser atestado através do grande número de anúncios encontrados nos Almanachs de Pelotas. Foi exatamente neste momento efervescente que circularam os objetos que aqui se analisa e nos quais se encontrava o público que se identificava, ou não, com a professora e com a enfermeira referenciadas textualmente ou imageticamente. A situação confortável que a cidade vivia sofre um grande golpe em 1931, quando a 
quebra do Banco Pelotense trouxe danos insuperáveis para o desenvolvimento da cidade. (CUNHA, 2009, p.38)

\subsection{Metodologia}

Os anúncios dos Almanachs de Pelotas já configuravam objeto de estudo da autora antes da realização da proposta de tese, dentro do grupo "Memória Gráfica de Pelotas: um século de design". Dentro deste grupo foi construído um formulário de identificação dos anúncios, para padronizar as análises que poderiam ser realizadas por diferentes pesquisadores. A definição dos dados que constituem este formulário pautaram-se em dados mais gerais (que podem ser úteis para futuras pesquisas ou para outros pesquisadores) e tópicos mais específicos para os interesses da pesquisa nos anúncios. Desta forma os dados constitutivos do formulário de identificação dos reclames foram estabelecidos da seguinte forma: título do periódico, data, página, cota, tipo de produto, estética, tema representado, tipo de impressão, gráfica, tipógrafo, dimensões, cores, suporte, observações. Abaixo segue um exemplo de formulário já preenchido com as devidas informações.

Tabela 1 - Exemplo de formulário de identificação dos reclames

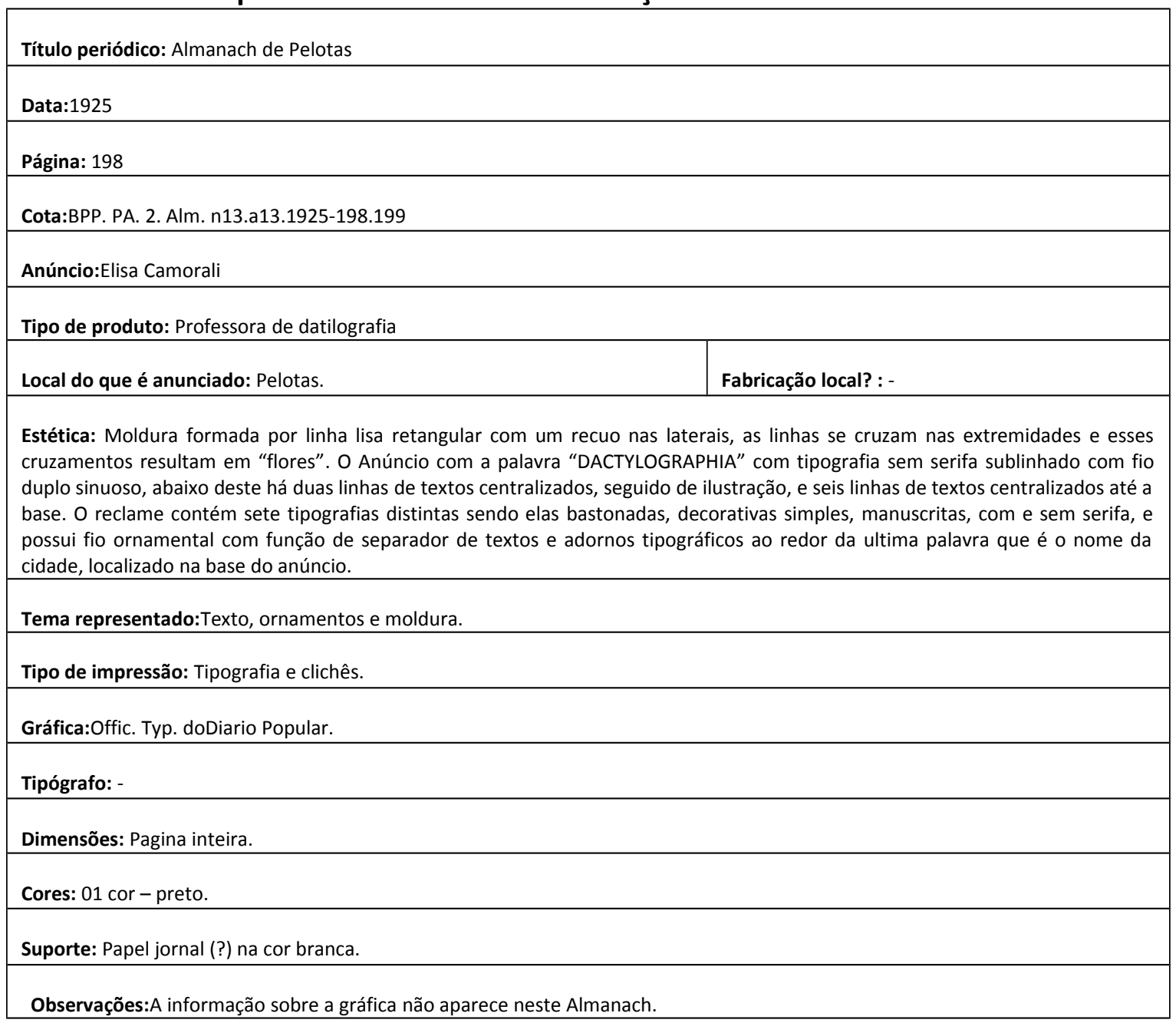


Fonte: Elaborado pelo autor, com base na pesquisa realizada no grupo Memória Gráfica de Pelotas. Preenchimento para o anúncio da Elisa Camorali, do Almanach de Pelotas de 1925, p. 198, realizado pela pesquisadora Yasmin Pormann Gonçalves

Com este modelo para orientar as análises têm-se dados relacionados ao suporte, ou seja, a própria publicação (tanto contextuais como materiais), levantamento de possíveis técnicas e nomes de profissionais (que podem auxiliar na construção da história da área na cidade) e tópicos mais reflexivos acerca da peça gráfica em si, como estética e tema representado. São estes dois itens do formulário que orientaram as análises dos anúncios que serão apresentados a seguir.

Importante destacar que, na investigação, foi contabilizado um total de 4221 anúncios nas 23 edições dos Almanachs de Pelotas. Deste grande manancial, apenas os dois modelos apresentados a seguir fazem menção a inserção da mulher no mundo do trabalho fora do lar.

\subsection{As análises}

Os reclames utilizados para a reflexão proposta neste ensaio são da Elisa Camorali (professora de datilografia), presente nas edições de 1925, 1926 e 1927 e anúncio da Cafiaspirina (medicamento), encontrado nas edições de 1930 e 1931. Em ambos os reclames, suas configurações apresentam-se exatamente iguais nas diferentes edições nas quais estão contidos.

O primeiro deles, referente a um serviço - Elisa Camorali, professora de datilografia - é composto por moldura de linhas retas com um recuo nas laterais, as quais se cruzam nas extremidades dando forma a "flores". O Anúncio destaca a palavra "Dactylographia" e contém outras informações, fazendo uso de sete tipografias distintas. Como tema representado, tem-se a ilustração de um homem bem vestido, datilografando em uma máquina de escrever, conforme demonstra a Figura 1. 


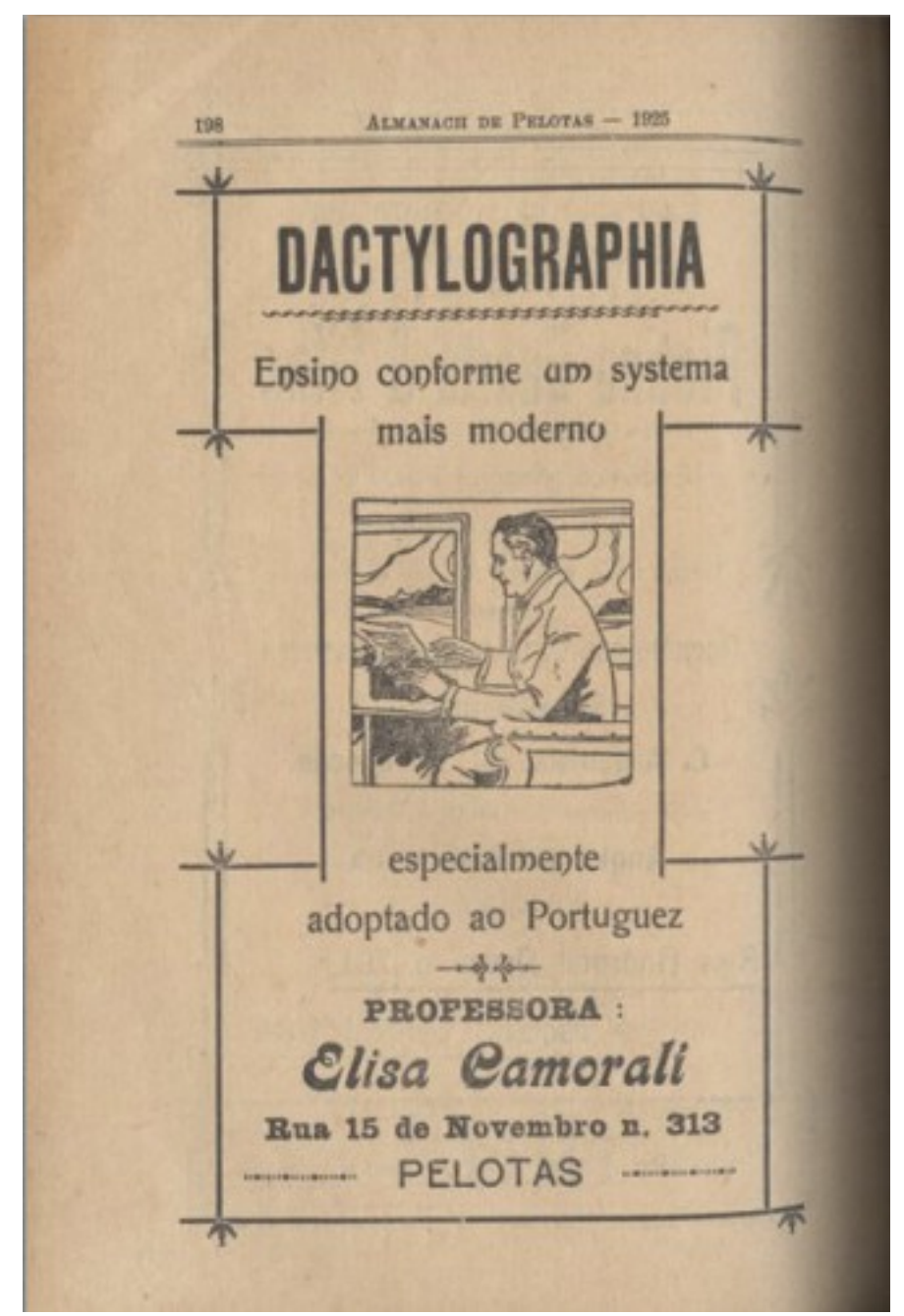

Figura 1 - Anúncio Elisa Camorali, professora de datilografia

Fonte: Almanach de Pelotas, 1925, p. 198, também presente nas edições de 1926 e 1927. Acervo da Bibliotheca Pública Pelotense.

Neste anúncio, o que chamou a atenção durante a pesquisa nos Almanachs foi, justamente, o fato de se tratar de um anúncio relativo a um serviço prestado por uma representante do gênero feminino. Até o momento este foi o único reclame encontrado que faz referência a um trabalho realizado por uma mulher como uma profissional e não como dona de casa. Interessante destacar que o serviço oferecido trata de uma profissão considerada feminina, a docência, conforme abordado anteriormente neste artigo.

Propagandear um serviço realizado por uma mulher é bastante inovador em se tratando do contexto estudado (tanto com relação ao veículo, quanto com relação ao espaço e ao tempo nos quais circulou), mas causa estranheza atentar-se para o fato de conter a ilustração de um homem. Assim sendo, a mulher até poderia "servir" para ensinar, mas talvez para datilografar em outros espaços, o mais confiável seria delegar esta tarefa aos homens

O segundo anúncio apreciado é o da Cafiaspirina, medicamento da marca Bayer. Este contém uma série de ornamentos como linhas e molduras, uma composta por pequenos elementos geométricos que intercalam com elementos que lembram cruzes portuguesas e outra formada por uma linha lisa e espessa. Também faz uso de 
inúmeras tipografias diferentes para a informação verbal o que, aliás, era uma prática recorrente nas demais amostras estudadas. No topo, à direita, há o elemento foco desta análise: uma ilustração de um homem (provavelmente um médico) falando com uma mulher que está trajada de enfermeira, conforme Figura 2.

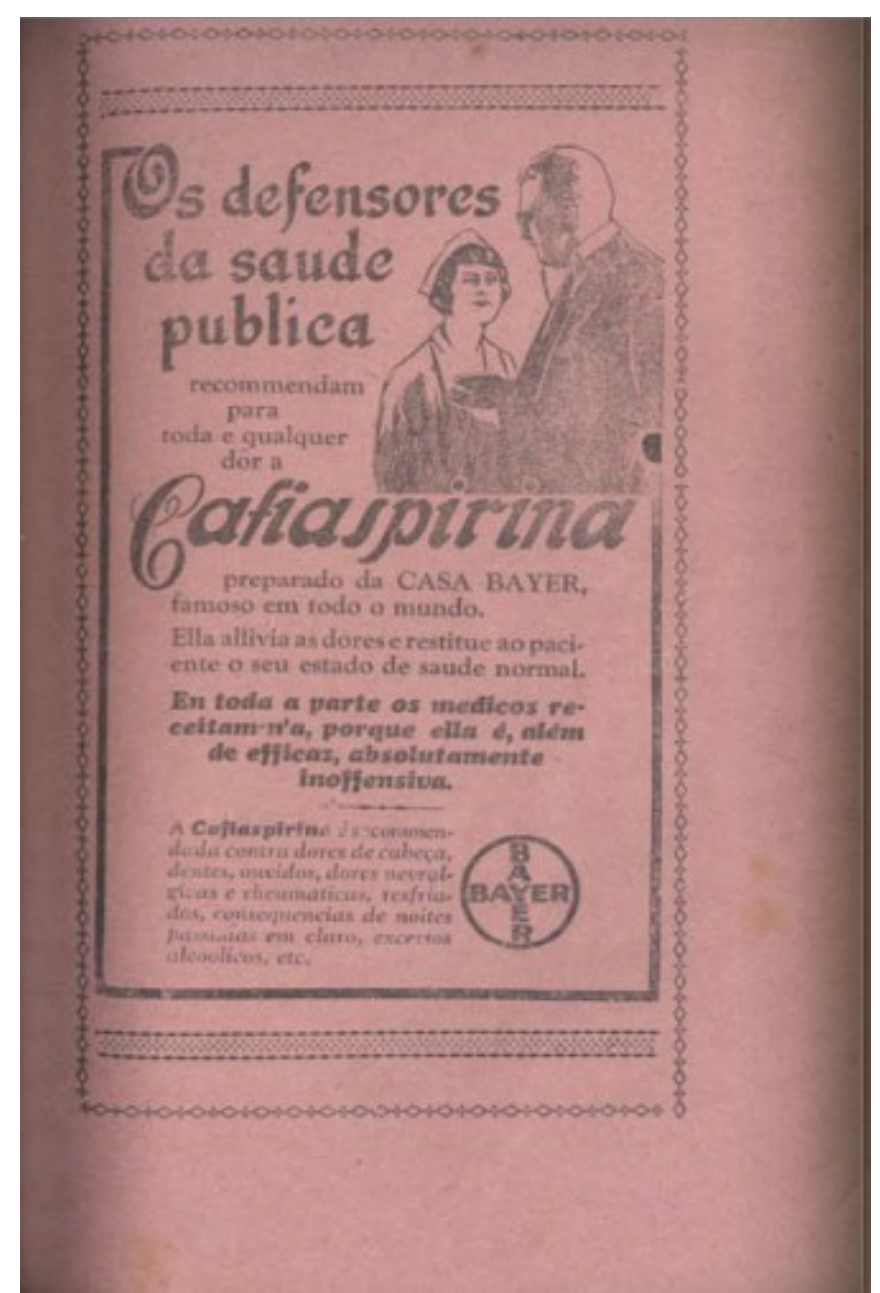

Figura 2 - Cafiaspirina - Bayer, medicamento

Fonte: Almanach de Pelotas, 1930, entre p.66 e p.67, também presente na edição de 1931. Acervo da Bibliotheca Pública Pelotense.

Neste caso não está sendo anunciado o serviço de uma mulher, mas há a ilustração que indica o trabalho feminino na enfermagem, mais uma vez uma profissão mencionada neste artigo quando da inserção de mulheres no trabalho fora do lar. No entanto, pode-se simbolicamente, ainda fazer interpretações acerca das diferenças de gênero: o homem em primeiro plano e a mulher em segundo; o homem grande e a mulher pequena. Sugere-se que isto não deve se tratar de um mero acaso, mas sim de uma estratégia nada ingênua, repleta de significados simbólicos, que instauram e/ou reforçam os papéis atribuídos aos atores daquele contexto. Isto reforça o pensamento de Funck (2007, p.190), acerca das propagandas como veículos de construção do mundo.

\section{CONCLUSÃO}


Tratar o objeto deste estudo - os reclames dos Almanachs de Pelotas - como peças gráficas cujo resultado pode contemplar o conceito de design, foi premissa básica e inicial. E, ao traçar as considerações finais, reafirma-se esta posição. Reiterase, inclusive, que esta postura deveu-se ao fato da existência de debate sobre localizações temporais para o surgimento da atividade de design gráfico no decurso da história e, também, pelo fato de que independente destas localizações acredita-se que deve ser relativizado aquilo que se enquadra ou não como objetos que contemplem esta definição. Conforme abordado, em qualquer uma das quatro correntes identificadas no estudo de Villas-Boas e Braga (2013) é possível ser acolhido neste sentido. No entanto, considera-se que classificar como sendo ou não design gráfico é mais genuíno se tomarmos como base o conceito da atividade, do seu produto e, neste sentido, também foi encontrado amparo que vai ao encontro da postura adotada. Considera-se que sim, se esta a trabalhar com produtos que identificam; informam e instruem; apresentam e promovem (HOLLIS, 2000, p.4).

Além disso, também se defende que estes reclames contém aspectos funcionais, formais, metodológicos e simbólicos (VILLAS-BOAS, 2000, p.8-12). Com relação ao aspecto formal, é possível perceber que os elementos comunicativos, verbais ou não verbais, relacionam-se entre si; sobre o aspecto funcional, não há dúvida que é estabelecida a comunicação com o receptor através dos textos e imagens; o aspecto metodológico também se considera estar presente em função da aplicação de um método projetual que possibilitou a materialização deste produto; e, por fim, o aspecto simbólico, também identificado em outros estudos debruçados em peças gráficas deste período como em Lima (2010), se faz presente. Ao se tomar os dois anúncios analisados neste artigo como exemplo, é possível detectar este aspecto. Por que um homem datilografando em um anúncio de uma professora de datilografia mulher? Por que um homem grande em primeiro plano e uma mulher menor e no segundo plano? Em ambos os casos, as significações simbólicas estão ali para serem interpretadas.

Recorrendo as peças consideradas como peças de design - os reclames - é interessante pensar que num contexto não vivenciado, mas não tão distante assim, são gritantes as diferenças entre os gêneros e dentro do gênero feminino no início do século XX e nos dias de hoje. Pensar que num grande manancial de 4221 anúncios foram localizados somente um modelo referente a um serviço prestado por uma mulher e um exemplar ilustrando uma mulher como uma profissional fora do lar é instigante. No primeiro caso estamos falando da Professora Elisa Camorali e, no segundo, de uma enfermeira sem identidade, apenas desenhada e impressa, talvez promulgando uma nova e possível mulher. Claro, a Bayer não era uma marca de Pelotas, esta cidade interiorana do sul do Rio Grande do Sul. Talvez em outros contextos mais desenvolvidos, essa mulher enfermeira fosse mais palpável que na cidade cenário da presente reflexão.

Embora a amostra apresentada seja exígua, justamente essa escassez é extremamente representativa da construção da categoria de gênero, dos papéis que eram estabelecidos para homens e mulheres, sendo o pouco incentivo às mulheres no que se refere ao trabalho remunerado, um exemplo das estipulações arbitrárias para a construção destes papéis. Com estes dois breves exemplos, impossível não entender o design como intimamente ligado ao contexto e a cultura nos quais circulou, como uma fonte de informações que traz dados inúmeros sobre estes cenários e também como 
uma fonte de construção destes cenários e de seus respectivos atores. Como não interpretar/identificar, através dos reclames analisados, as relações entre os gêneros e as relações das mulheres do início do século XX com o mundo do trabalho para além das paredes de seus lares? Questões simbólicas nada ingênuas que demonstram os papéis ao mesmo tempo que os reforçam.

Dentre as próximas etapas da pesquisa, está previsto sistematizar todos os reclames dos Almanachs de Pelotas de uma forma mais específica, com foco nas suas representações gráficas e que possibilite visualizar aspectos de gênero feminino e gênero masculino. Essa sistematização se baseará no preenchimento de tabelas subdivididas em categorias como iconográfico e não iconográfico. $O$ item iconográfico, por sua vez, subdivide-se em anúncios nos quais aparecem figura da mulher, figura do homem, figura do produto, figura da fachada e ornamentos/estética. Dentro dessas subcategorias ainda objetiva-se averiguar se o reclame destina-se às mulheres, aos homens, a ambos ou se é neutro. Na categoria não iconográfico não existem subcategorias, procedendo-se apenas a averiguação de direcionamento do produto ou serviço (mulher, homem, ambos, neutro) como já descrito na categoria anterior. Espera-se, a partir desta próxima etapa, estabelecer maiores relações entre as representações gráficas no design dos reclames e as questões de gênero.

\section{REFERÊNCIAS}

CUNHA, Jaqueline Rosa da. A formação do sistema literário de Pelotas: uma contribuição para a literatura do Rio Grande do Sul. Tese (Programa de Pós-Graduação em Letras) - Pontifícia Universidade Católica do Rio Grande do Sul, Porto Alegre, 2009.

DENIS, Rafael Cardoso. Uma introdução à história do design. São Paulo: Edgard Blücher, 2000.

DUTRA, Eliane de Freitas. Rebeldes literários da República: história e identidade nacional no Almanach Brasileiro Garnier (1913-1914). Belo Horizonte: Editora UFMG, 2005.

FUNCK, Susana. Discurso e identidade de gênero. In: CALDAS-COULTHARD, Carmen Rosa; SCLIAR-CABRAL, Leonor (Org.). Desvendando discursos: conceitos básicos. Florianópolis: EDUFSC, 2007. p.183-195.

GASTAUD, Carla; SILVA, Fernanda Oliveira da. Dicionário de História de Pelotas. Beatriz Ana Loner, Lorena Almeida Gill, Mario Osório Magalhães (organizadores). Pelotas: Ed. da Ufpel, 2010.

MARRONI, Fabiane Villela. Pelotas (re)vista: a Belle Époque da cidade através da mídia impressa. Tese (Doutorado em Comunicação e Semiótica) - Pontifícia Universidade Católica de São Paulo, São Paulo, 2008.

MEGGS, Philip; PURVIS, Alston W. História do Design Gráfico. Tradução de Cid Knipel. São Paulo: Cosac \& Naify, 2009. 
LIMA, Paula Garcia. Estudo da memória e do conceito de design através das peças gráficas e fotografias do Parque Souza Soares (Pelotas, 1900-1930). Dissertação (Programa de Pós-Graduação em Memória Social e Patrimônio Cultural) Universidade Federal de Pelotas, Pelotas, 2010.

PERROT, Michelle. Minha história das mulheres. 2.ed. São Paulo: Contexto, 2012

VILLAS-BOAS, André; BRAGA, Marcos da Costa. O objeto como norte: origens e periodização na historiografia do design gráfico. In: ALMEIDA, Marcelina das Graças; REZENDE, Edson José Carpintero; SAFAR, Giselle Hissa; MENDONÇA, Roxane Sidney Resende (Org.). Caderno a tempo : histórias em arte e design. Barbacena : EdUEMG, 2013. p.25-45.

VILLAS-BOAS, André. 0 que é e o que nunca foi design gráfico. Rio de Janeiro: $2 A B, 2000$.

\section{Fontes consultadas}

PARADEDA, Florentino. Almanachs de Pelotas (1913 - 1920). Pelotas: Officinas Typographicas do Diário Popular. Acervo Histórico da Bibliotheca Pública de Pelotas.

PARADEDA, Florentino. Almanachs de Pelotas (1921 - 1928). Pelotas: Tipografia A Guarany. Acervo Histórico da Bibliotheca Pública de Pelotas.

PARADEDA, Florentino. Almanachs de Pelotas (1929 - 1935). Pelotas: Tipografia Livraria do Globo. Acervo Histórico da Bibliotheca Pública de Pelotas. 